\title{
Competitive Situations and Significance of Management Accounting System in Business Firms of Nepal
}

\author{
Dr. Dilip Parajuli \\ Associate Professor, Bhaktapur Multiple Campus, Tribhuvan University, Nepal \\ Dr. Prakash Shrestha* \\ Lecturer, Nepal Commerce Campus, Tribhuvan University, Nepal
}

\begin{abstract}
The purpose of this study is to examine the significant factors of the management accounting system (MAS) in Nepalese business firms and to examine whether these factors differ in three competitive situations, such as the low, moderate, and high level of competition. It presents the results based on a survey of business firms including sole trading, partnership, and private limited manufacturing firms of industrial estates of Nepal. The structured questionnaires were distributed to the financial managers, production managers, and operations managers of the sampled firms. For the purposes of the study, 83.33 percent of the questionnaire was collected and used. This study shows that the management accounting system has been used by most businesses as a compilation of information to determine from the perspective of its significance, and the management accounting system used is very effective and has led to the success of business firms. Mainly, this study has explored three major significant factors of MAS such as decision-making and performance analysis, proper allocation of resources and cost reduction, and planning and budgeting tool. The findings of this research provide a useful guideline to business firms, especially their managers, to make decisions in light of the current changing management accounting system and competitive situations.
\end{abstract}

Keywords: Business firms, Competitive situation, Factors, Management accounting system, Significance

DOI: $10.7176 /$ RJFA/11-24-01

Publication date: December $31^{\text {st }} 2020$

\section{Introduction}

Management accounting systems (MAS) is the systematic use of management accounting that meets organizational objectives. It is an important part of the management process. It deals with the provision and use of financial and operational information for managers within decision-making, planning, and control organizations (Zaleha Abdul Rasid, Ruhana Isa, \& Khairuzzaman Wan Ismail, 2014). Businesses are becoming more aggressive and dynamic in finding strategic tactics that will ensure a sustainable life as today's business environment becomes strategic (Shah, 2009). Competition between business firms will cause management to establish business strategies and strategies to maximize profit for an organization (Thompson, Strickland, \& Gamble (2009). This can be done by increased revenue and lowered manufacturing costs. Profit optimization and cost minimization can allow a business to build a competitive advantage in its industry. Some management accounting practices include techniques that can influence a large number of customers to have a lifelong preference for the goods of a business. In such a context, Thompson et al. (2009) further assume that the use of MAS will provide a sustainable competitive advantage for a company over its competitors.

Collier (2009) notes that MAS is an important part of the core management process that needs information used by management to be defined, calculated, accumulated, evaluated, prepared, interpreted, and communicated. It is used by an entity to plan, analyze, monitor, and ensure the effective use of and transparency for its economic resources. Business firms use MAS to assess their operations. MAS techniques include budgeting, variance analysis, and breakeven analysis. These techniques assist these firms in planning, directing and controlling operating expenses and achieving profitability. Management accounting activities are regarded as critical to the performance of the organization (Horngren et al., 2009). Ittner and Larcker (2002) reported management accounting practices as a variety of methods specially considered for business firms to support their infrastructure and management accounting processes. They have also argued that the emergence of these new approaches has modified the fundamental concepts of management accounting to a higher one that adds value to different business activities. Some studies (e.g., Chenhall, 2003; Ismail and Isa, 2011) also reported that well-designed and sufficient MAS allow managers to be more successful in decision-making, allowing companies to boost their competitiveness and stay competitive in a challenging environment that is often demanding. This will consequently boost the efficiency of the companies. Thus, this study is concerned with the significance of MAS in business firms in Nepal. 


\section{Purpose of the Study}

The purpose of this study is to examine the significant factors of the management accounting system in Nepalese business firms and to examine whether these factors differ in three competitive situations, such as the low, moderate, and high level of competition.

\section{Literature Review}

MAS is one of the most critical components of the structured planning and control system of an organization. It is intended to provide information useful to managers within it (Chenhall and Morris, 1986; Chenhall, 2003). Many accounting literature sources (e.g., Mia \& Chenhall, 1994; Ittner \& Larcker, 2002; Naranjo-Gil \& van Rinsum, 2006; Hilton, 2008; Thompson et al., 2009; Sharma, 2011; Sunarni, 2013; Sharma, 2015; Dahlan, 2017; and Dahlan, 2019) have reported the role of MAS.

In the past, when they were in charge of both financial accounting and cost accounting activities, management accountants were referred to as controllers (Horngren et al., 2009). Shah (2009), however, claims that modern management accountants play a dual role: they are accountable for the competence of top management and should be accountable for assisting departmental managers in the organization's planning and control activities. In addition, Hilton (2008) points out that the management accountants advise and provide useful knowledge that directs an organization to achieve its goals. MAS helps the management accountants to perform their performance effectively. $\mathrm{Wu}$ and Boateng (2010) argue that some variables such as the size of a firm, partners and the expertise of senior managers and employees may influence the change in management accounting practices, and they again added that the success with which these variables are known can positively influence the growth of an organization and the economy in general.

Therefore, as a way to build a competitive advantage, this information may have allowed business firms to establish strategies that vary with their scale, area of activity, and management. Sunarni (2013) also reported that it is through management accounting that managers get the tools to execute their tasks. Sharma (2015) reported the usefulness of MAS in decision-making. Dahlan $(2017,2019)$ also reported that MAS is useful to enhance both innovation and firm performance. Both variables of MAS information and interactive budget use significantly boost performance. The empirical studies presenting significance of MAS in business enterprises are presented below:

Table 1: The Empirical Studies on Management Accounting System (MAS)

\begin{tabular}{|l|l|}
\hline Researcher(s)/Date & Major Findings \\
\hline Mia \& Chenhall (1994) & MAS is useful for functional differentiation and managerial effectiveness. \\
\hline Ittner \& Larcker (2002) & $\begin{array}{l}\text { Management accounting practices as a variety of methods specially considered } \\
\text { for manufacturing businesses to support the organization's infrastructure and } \\
\text { management accounting processes. }\end{array}$ \\
\hline $\begin{array}{l}\text { Naranjo-Gil \& van } \\
\text { Rinsum (2006) }\end{array}$ & $\begin{array}{l}\text { There is a relationship between the design of the MAS, management style, and } \\
\text { organizational performance. }\end{array}$ \\
\hline Hilton (2008) & $\begin{array}{l}\text { Companies are interested in issuing formal procedures to decrease costs through } \\
\text { linking activity-based costing with the target costing adopted by the management } \\
\text { of companies. }\end{array}$ \\
\hline Thompson et al. (2009) & $\begin{array}{l}\text { Competition amongst business organizations may compel the management to } \\
\text { develop business techniques and strategies that would guide an organization } \\
\text { towards the maximization of profit. }\end{array}$ \\
\hline Sharma (2011) & $\begin{array}{l}\text { Management accounting systems help to develop a manufacturing strategy for } \\
\text { manufacturing units. }\end{array}$ \\
\hline Sunarni (2013) & $\begin{array}{l}\text { Management accounting provides tools that allow managers to execute their } \\
\text { tasks. }\end{array}$ \\
\hline Sharma (2015) & $\begin{array}{l}\text { Management accounting reports were perceived to be more useful and decision- } \\
\text { making tool than financial accounting reports. }\end{array}$ \\
\hline Dahlan (2017) & $\begin{array}{l}\text { MAS is useful to enhance both innovation and firm performance. } \\
\text { information and interactive budget use significantly boost job performance. }\end{array}$ \\
\hline Dahlan (2019) &
\end{tabular}

\section{Research Methodology \\ Research Design}

This research uses an exploratory research design to explore the significance of the MAS accounting system in Nepalese business firms.

Sample and Participants

In total 50 business firms (including sole trading, partnership, and private limited manufacturing firms) of four 
industrial estates of Nepal (namely, Balaju Industrial Estate, Bhaktapur Industrial Estate, Patan Industrial Estate, and Pokhara Industrial Estate) were selected as sample firms. The respondents were employees of these sample firms employed as managers of finance, productions and operations departments.

\section{Source of Data}

A survey through a structured questionnaire was taken as a source of data for this study. The questionnaires were distributed to 90 financial, production, and operation managers of the selected firms. Only 83.33 percent of useful questionnaires were received and use for data analysis purposes.

\section{Measurement of MAS}

The significance of MAS is measured using the scale developed by Abdel and Luther (2006), which is slightly modified to make it clear to Nepalese people. All the items are measured on a five-point Likert-type scale from "disagree totally (1)" to "agree totally (5)".

\section{Tools for Analysis}

Descriptive analysis with a statistical significance test and factor analysis was adopted as tools for data analysis. Mainly, KMO and Bartletts's Test, Analysis of Variances (ANOVA) Test, and Post-Hoc Comparisons Means were used. Also used to assess reliability was Cronbach's alpha. The alpha value measured is 0.91, which is greater than the reported estimate, and it is argued that the methods used in this research are sufficiently reliable.

\section{Results and Findings}

\section{Significance of MAS}

This section presents the MAS in terms of controlling and evaluating performance, providing information for top and lower level management for decision-making, providing information for allocation of cost, preparing financial statements, pricing decision, cost control and reduction, help allocating resources to be used more effectively, help coordinating activities, and planning and budgeting in business firms of Nepal. In this regard, participants are requested to rate the significance of MAS. The significance measures, as well as various important indicators, have been identified and such measures and indicators are provided with their respective lodging factors in Table (3).

Table (2) shows that the Kaiser-Meyer-Olkin sampling adequacy value measure is 0.703 , which is closer to 1 and the Bartlett Sphericity Test is significant. Taken together, these tests provide a minimum standard that should be passed before a factor analysis should be carried out.

Table 2: KMO and Bartletts's Test

\begin{tabular}{|l|c|c|}
\hline \multicolumn{2}{|c|}{ Kaiser-Meyer-Olkin Measure of Sampling Adequacy. } & 0.703 \\
\hline \multirow{3}{*}{ Bartlett's Test of Sphericity } & Approx. Chi-Square & 98.392 \\
\cline { 2 - 3 } & Df & 49 \\
\cline { 2 - 3 } & Sig. & 0.000 \\
\hline
\end{tabular}

Table 3: Total Variance of Management Accounting Significance Factors

\begin{tabular}{|c|c|c|c|c|c|}
\hline $\begin{array}{c}\text { Significance of Management } \\
\text { Accounting System }\end{array}$ & $\begin{array}{l}\text { Decision-making and } \\
\text { performance analysis } \\
\text { Factor- } 1\end{array}$ & $\begin{array}{l}\text { Proper } \\
\text { resources } \\
\text { use and } \\
\text { cost } \\
\text { control } \\
\text { Factor-2 }\end{array}$ & $\begin{array}{l}\text { Plan } \\
\text { ning } \\
\text { and } \\
\text { budg } \\
\text { eting } \\
\text { Fact } \\
\text { or-3 }\end{array}$ & $\begin{array}{c}\text { Commu } \\
\text { nalities } \\
\left(\mathbf{h}^{2}\right)\end{array}$ & $\begin{array}{c}\text { Al } \\
\text { ph } \\
\text { a } \\
(\alpha)\end{array}$ \\
\hline Controlling and evaluating performance & 0.928 & & & 0.919 & \multirow{9}{*}{$\begin{array}{c}0.9 \\
1\end{array}$} \\
\hline $\begin{array}{l}\text { Providing information for top and lower } \\
\text { level management for decision-making }\end{array}$ & 0.89 & & & 0.928 & \\
\hline $\begin{array}{l}\text { Providing information for allocation of } \\
\text { cost }\end{array}$ & 0.84 & & & 0.853 & \\
\hline Preparing financial statements & 0.817 & & & 0.824 & \\
\hline Pricing decision & 0.767 & & & 0.950 & \\
\hline Cost control and reduction & & 0.954 & & 0.914 & \\
\hline $\begin{array}{l}\text { Help allocating resources to be used more } \\
\text { effectively }\end{array}$ & & 0.826 & & 0.878 & \\
\hline Help coordinating activities & & & 0.633 & 0.889 & \\
\hline Planning and budgeting & & & 0.606 & 0.661 & \\
\hline Variance extracted & 5.31 & 1.78 & 1.24 & 7.816 & \\
\hline$\%$ of variance extracted & 53.12 & 17.88 & 12.43 & 83.43 & \\
\hline
\end{tabular}

Table (3) presents that three factors have emerged regarding the importance of the management accounting system. The extraction method was used as Principal Component Analysis and Varimax with Kaiser Normalization 
as a rotation method to locate these factors. 53.12 percent of the total variance was extracted by the first factor, 17.88 percent of the total variance was extracted by the second factor, and 12.43 percent was extracted by the third factor. According to the eigenvalue, the number of factors greater than 1.0 criterion was extracted.

These three main variables accounted for 83.43 percent of the overall variation in the significance of the management accounting system. We may conclude and mark from factor- 1 that decision-making and performance analysis is one of the major significant components of the management accounting system. Factor-2 demonstrates that proper allocation of resources and cost reduction has emerged as another significant factor in the management accounting system and helps to distribute resources and can be used more efficiently. Finally, as a planning and budgeting tool of the management accounting system, factor-3 has arisen. In order to devise the operational strategy and budget, it coordinates the different organizational tasks.

\section{Competitive Situation and Significance Factors}

The empirical results indicate that $72 \%$ of business firms operated at a high level of business competition, $18 \%$ of business firms operated at a medium level of business competition, and only $10 \%$ of business firms operated at a low level of competition. The results are presented in Table (4).

Table 4: Competitive Situations

\begin{tabular}{|l|c|}
\hline \multicolumn{1}{|c|}{ Competitive Situations } & Percent \\
\hline Competition is low & 10 \\
\hline Competition is moderate & 18 \\
\hline Competition is high & 72 \\
\hline Note: No. of total business firms $=50$ & \\
\hline
\end{tabular}

As this study explored three major factors of the significance of MAS as presented in Table (3) such as decision-making and performance analysis, proper recourses use and cost control, and planning and budgeting. Therefore, this study tried to examine whether these significant factors of the management accounting system differ among these three competitive situations such as competition situation is low, moderate, and high. The results are presented in Table (5).

Table 5: Estimates of Mean of Significance of MAS across the three Competitive Situations

\begin{tabular}{llcccc}
\hline Significance of MAS & Competitive Situation & $\mathbf{N}$ & Mean & S.D. & S.E. \\
\hline \multirow{4}{*}{ Decision making and performance analysis } & Low & 5 & 19.50 & 1.00 & 0.29 \\
\cline { 2 - 5 } & Moderate & 9 & 17.83 & 0.75 & 0.31 \\
\cline { 2 - 5 } & High & 36 & 18.13 & 4.30 & 0.59 \\
\cline { 2 - 5 } & Total & 50 & 18.34 & 3.77 & 0.45 \\
\hline \multirow{3}{*}{ Proper resources use and cost control } & Low & 5 & 6.50 & 0.52 & 0.15 \\
\cline { 2 - 5 } & Moderate & 9 & 7.00 & 0.00 & 0.00 \\
\cline { 2 - 5 } & High & 36 & 5.08 & 1.50 & 0.21 \\
\cline { 2 - 5 } & Total & 50 & 5.48 & 1.49 & 0.18 \\
\hline \multirow{3}{*}{ Planning and budgeting } & Low & 5 & 12.00 & 2.09 & 0.60 \\
\cline { 2 - 5 } & Moderate & 9 & 10.00 & 0.00 & 0.00 \\
\cline { 2 - 5 } & High & 36 & 7.87 & 2.16 & 0.30 \\
\cline { 2 - 5 } & Total & 50 & 8.75 & 2.58 & 0.31 \\
\cline { 2 - 5 } & & & &
\end{tabular}

Table 6: Analysis of Variances (ANOVA) Test

\begin{tabular}{|c|c|c|c|c|c|c|}
\hline Significance of MAS & $\begin{array}{l}\text { Sources of } \\
\text { Variance }\end{array}$ & $\begin{array}{l}\text { Sum of } \\
\text { Squares }\end{array}$ & df & $\begin{array}{l}\text { Mean } \\
\text { Square }\end{array}$ & $\mathbf{F}$ & Sig. \\
\hline \multirow{2}{*}{$\begin{array}{c}\text { Decision-making and performance } \\
\text { analysis }\end{array}$} & Between Groups & 19.98 & 2 & 9.99 & 0.70 & \multirow[t]{2}{*}{0.50} \\
\hline & Within Groups & 973.91 & 68 & 14.32 & & \\
\hline \multirow{2}{*}{ Proper resources use and cost control } & Between Groups & 35.02 & 2 & 17.51 & 9.87 & \multirow{2}{*}{$\begin{array}{c}0.00 \\
*\end{array}$} \\
\hline & Within Groups & 120.70 & 68 & 1.78 & & \\
\hline \multirow{2}{*}{ Planning and budgeting } & Between Grouns & 17736 & 2 & 8868 & 20.7 & \multirow{2}{*}{$\begin{array}{c}0.00 \\
*\end{array}$} \\
\hline & $\begin{array}{l}\text { Between Groups } \\
\text { Within Groups }\end{array}$ & $\frac{171.36}{290.08}$ & $\frac{2}{68}$ & $\begin{array}{l}88.08 \\
4.27\end{array}$ & & \\
\hline
\end{tabular}

Note: Significant at ${ }^{*} p<0.05$

The results in the above table show that the p-value of the t-test is high as compared to the $5 \%$ level of significance under decision-making and performance analysis significance of management accounting techniques. Therefore, there is no significant mean difference in decision-making and performance analysis as management accounting significance across the three firm types. However, the p-value of the t-test is low under proper resources use and cost control, and planning and budgeting significance of management accounting techniques as compared to the $5 \%$ level of significance. Therefore, it can be concluded that there is a significant mean difference in these 
factors as management accounting significance across the three firm types. Therefore, it remains to test through Post-Hoc Comparisons Means which of the means are significantly different.

Table 7: Post-Hoc Comparison of Means of Management Accounting Significance on Current Competitive Situation

\begin{tabular}{|c|c|c|c|c|c|}
\hline Dependent Variable & $\begin{array}{c}\text { (A) Current } \\
\text { Competitive Situation }\end{array}$ & $\begin{array}{c}\text { (B) Current } \\
\text { Competitive Situation }\end{array}$ & $\begin{array}{c}\text { Mean } \\
\text { Diff. } \\
\text { (A-B) }\end{array}$ & $\begin{array}{c}\text { Std. } \\
\text { Erro } \\
\quad r \\
\end{array}$ & Sig. \\
\hline \multirow{6}{*}{$\begin{array}{l}\text { Decision making and } \\
\text { performance analysis }\end{array}$} & \multirow{2}{*}{ Low } & Moderate & 1.67 & 1.89 & 0.38 \\
\hline & & High & 1.37 & 1.21 & 0.26 \\
\hline & \multirow{2}{*}{ Moderate } & Low & -1.67 & 1.89 & 0.38 \\
\hline & & High & -0.30 & 1.63 & 0.86 \\
\hline & \multirow{2}{*}{ High } & Low & -1.37 & 1.21 & 0.26 \\
\hline & & Moderate & 0.30 & 1.63 & 0.86 \\
\hline \multirow{6}{*}{$\begin{array}{l}\text { Proper resources use and } \\
\text { cost control }\end{array}$} & \multirow{2}{*}{ Low } & Moderate & -0.50 & 0.67 & 0.46 \\
\hline & & High & 1.42 & 0.43 & 0.00 \\
\hline & \multirow{2}{*}{ Moderate } & Low & 0.50 & 0.67 & 0.46 \\
\hline & & High & $1.92 *$ & 0.57 & 0.00 \\
\hline & \multirow{2}{*}{ High } & Low & $-1.42 *$ & 0.43 & 0.00 \\
\hline & & Moderate & $-1.92 *$ & 0.57 & 0.00 \\
\hline \multirow{6}{*}{ Planning and budgeting } & \multirow{2}{*}{ Low } & Moderate & 2.00 & 1.03 & 0.06 \\
\hline & & High & $4.13 *$ & 0.66 & 0.00 \\
\hline & \multirow{2}{*}{ Moderate } & Low & -2.00 & 1.03 & 0.06 \\
\hline & & High & $2.13 *$ & 0.89 & 0.02 \\
\hline & \multirow{2}{*}{ High } & Low & $-4.13 *$ & 0.66 & 0.00 \\
\hline & & Moderate & $-2.13 *$ & 0.89 & 0.02 \\
\hline
\end{tabular}

Note: Significant at $* p<0.05$

The results in the above table reveal that the p-value of the Post- Hoc comparisons test is high as compared to the $5 \%$ level of significance and it can be concluded that there is no significant mean difference of proper resources use and cost control as management accounting significance between the company type-competitions are high and competition is moderate. Similarly, the p-value of the Post- Hoc comparisons test is high as compared to the $5 \%$ level of significance, and we conclude that there is no significant mean difference in planning and budgeting significance between the company type-competitions are low and competition is moderate.

\section{Discussion and Conclusion}

The results showed that the major three significant factors of MAS are decision-making and performance analysis, proper allocation of resources and cost reduction, and planning and budgeting tool. The first factor, decisionmaking and performance analysis includes controlling and evaluating performance, providing information for top and lower-level management for decision-making, providing information for allocation of cost, preparing financial statements, and pricing decision) is one of the major significant components of the management accounting system. The second factor, proper allocation of resources and cost reduction involves cost control and reduction, and help allocating resources to be used more effectively. Finally, the third factor, the planning and budgeting tool helps in coordinating activities of the firm. This result is consistent with Abdel and Luther (2006), Ittner \& Larcker (2002), Sharma (2011), and Dahlan (2019) as well. They found that in costing, budgeting, program evaluation, decision-making information, and strategic analysis, the importance of the management accounting method was significant.

Thus, we can conclude from this current result that other businesses often require management accounting practices to make the correct decision in successful and efficient ways about the costing, planning, budgeting, and pricing of products or services. This is because each business's profitability depends on internal planning and decision-making. Therefore, for the management, marketing, finance, and inventory divisions of each business firm, these management accounting reports are typically more relevant.

\section{Practical Implications}

Business firms use the management accounting system as a collection of information to make a decision from the perspective of its significance. The study shows that management accounting system employed within the three competitive situations are very effective and contributed to the success of the business firms. By employing an applicable and reliable methodology, this study has significantly contributed to the theoretical and methodological knowledge in the area of management accounting systems and three competitive situations. The findings of this research also provide a useful guideline to business firms, especially their managers, to make decisions in light of 
the current changing management accounting system and competitive situations.

\section{References}

Abdel, K. M., \& Luther, R. (2006). Management accounting practices in the British food and drinks industries. British Food Journal, 10(5), 336-357.

Chenhall, R.H. (2003). Management control systems design within its organizational context: findings from contingency-based research and directions for the future. Accounting, Organizations and Society, 28(2/3), 127-168.

Chenhall, R.H., \& Morris, D. (1986). The impact of structure, environment, and interdependence on the perceived usefulness of management accounting systems. The Accounting Review, 61, 16-35.

Collier, P. M.(2009). Accounting for managers: interpreting accounting information for decision-making (3rd ed). England John Wiley and Sons Inc, West Sussex.

Dahlan, M. (2017). Moderating effect of usefulness management accounting system on the relationship between innovation and firm performance: evidence from Bandung District, West Java, Indonesia. International Journal of Applied Business and Economic Research, 15(25), 179-188.

Dahlana, M. (2019). Analysis of interrelationship between usefulness of management accounting systems, interactive budget use and job performance. Management Science Letters, 9, 967-972.

Hilton, R., (2008), Management accounting-creating value in a dynamic business environment. USA: McGrawHill Publications.

Horngren, C.T., Sundem, G.L., Stratton, W.O., Schatzberg, J., \& Burgstahler, D. (2009). Introduction to management accounting. (4 $4^{\text {th }}$. ed). New York: Prentice Hall.

Ismail, K., \& Isa, C.R. (2011). The role of management accounting systems in advanced manufacturing environment. Australian Journal of Basic and Applied Sciences, 5(9), 2196-2209.

Ittner, C., \& Larcker, D. (2002). Assessing empirical search in managerial accounting: a value-based management perspective. Journal of Accounting and Economics, 32(1-3), 349-410.

Mia, L., \& Chenhall, R. H. (1994). The usefulness of management accounting systems, functional differentiation and managerial effectiveness. Accounting, Organizations and Society, 19(1), 1-13.

Naranjo-Gil, D., \& van Rinsum, M. (2006). The effect of management style and management accounting system design on performance. JAMAR, 4(1), 33-44.

Shah, P. (2009). Management Accounting. New Delhi: Oxford University Press.

Sharma G. (2011). Manufacturing strategy and role of management accounting system: A study on manufacturing units of Pokhara. PACE, the Journal of Business and Management, 3(1), 92-101.

Sharma, G. (2015). Practices of financial and management accounting: Evidence from small and medium-sized enterprises of Nepal. The Journal of Nepalese Business Studies, 9(1), 77-86.

Sunarni, C.W. (2013). Management accounting practices and the role of management accountant: Evidence from manufacturing companies throughout Yogyakarta, Indonesia. Review of Integrative Business and Economic Research, 2(2), 616-626.

Thompson, A.A., Strickland, A.J., \& Gamble, J.E.(2009). The quest for competitive advantage: concepts and cases (17th ed). New Delhi: McGraw-Hill.

Wu, J., \& Boateng, A. (2010). Factors influencing changes in Chinese management accounting practices. Journal of Change Management, 10(3), 315-329.

Zaleha Abdul Rasid, S., Ruhana Isa, C., \& Khairuzzaman Wan Ismail, W. (2014). Management accounting systems, enterprise risk management and organizational performance in financial institutions. Asian Review of Accounting, 22(2), 128-144. 